\title{
Influence of Angiotensin II Receptor Subtypes of the Paraventricular Nucleus on the Physiological Responses Induced by Angiotensin II Injection into the Medial Septal Area
}

\author{
Wilson Abrão Saad, Luiz Antonio de Arruda Camargo \\ Araraquara - Taubaté, SP - Brazil
}

Objective - We determined the effects of losartan and $P D 123319$ (antagonists of the $A T$, and $A T$, angiotensin receptors, respectively), and $\left[\mathrm{Sar}^{l}, \mathrm{Ala}^{8}\right] \mathrm{ANG}$ II (a relatively peptide antagonist of angiotensin receptors) injected into the paraventricular nucleus (PVN) on water and $3 \% \mathrm{NaCl}$ intake, and the diuretic, natriuretic, and pressor effects induced by administration of angiotensin II (ANG II) into the medial septal area (MSA) of conscious rats.

Methods - Holtzman rats were used. Animals were anesthetized with tribromoethanol $(20 \mathrm{mg})$ per 100 grams of body weight, ip. A stainless steel guide cannula was implanted into the MSA and PVN. All drugs were injected in 0.5- $\mu l$ volumes for 10-15 seconds. Seven days after brain surgery, water and 3\% $\mathrm{NaCl}$ intake, urine and sodium excretion, and arterial blood pressure were measured.

Results -Losartan (40 nmol) and [Sar ${ }^{1}$, Ala $\left.^{8}\right]$ ANG II (40 nmol) completely eliminated whereas PD 123319 (40 nmol) partially blocked the increase in water and sodium intake and the increase in arterial blood pressure induced by ANG II (10 nmol) injected into the MSA. The PVNadministration of PD 123319 and $\left[\mathrm{Sar}^{l}, \mathrm{Ala}^{8}\right]$ ANG II blocked whereas losartan attenuated the diuresis and natriuresis induced by MSA administration of ANG II.

Conclusion - MSA involvement with PVN on water and sodium homeostasis and arterial pressure modulation utilizing ANGII receptors is suggested.

Keywords: central nervous system, blood pressure, sodium balance

Department of Physiology, School of Dentistry, Paulista State University, UNESP, Araraquara, and Department of Medicine and Dentistry, Taubaté University, UNITAU, Taubaté.

Correspondence: Wilson Abrão Saad - Department of Physiology, School of Dentistry - Paulista State University, UNESP - Rua Humaitá, 1680 - 14801-903 - Araraquara, SP - Brazil - E-mail: silvana@foar.unesp.br
Considerable evidence supports the notion that brain angiotensin II (ANG II) plays an important role in the regulation of pressor responses, thirst, sodium appetite, and release of vasopressin ${ }^{1-3}$. The paraventricular nucleus of the hypothalamus (PVN) is known to be an important center for integrating the neural signals of pressor response ${ }^{4,5}$, the regulation of vasopressin release from the pituitary ${ }^{6,7}$, and the mediation of the dipsogenic action of ANGII [5]. The medial septal area (MAS) as well as the PVN are brain structures involved in fluid electrolytic and cardiovascular regulation $^{8-13}$.

Recently, 2 angiotensin receptor subtypes 1 and 2 have been identified on the basis of selective antagonists. Although most brain nuclei expressing ANG II receptors contain only 1 subtype, some nuclei express a mixture of $\mathrm{AT}_{1}$ and $\mathrm{AT}_{2}$ receptors ${ }^{14,15}$.

PVN is known to contain predominantly $\mathrm{AT}_{1}$ subtype receptors ${ }^{16,17}$, but it has been shown that the excitatory action of angiotensin on paraventricular neurons is also antagonized by the ANG II receptor subtype $\mathrm{AT}_{2}{ }^{18-20}$. Both $\mathrm{AT}_{1}$ and $\mathrm{AT}_{2}$ sites are also found in the septum ${ }^{21}$.

Because the septum has known anatomic connections with PVN ${ }^{8,13,22}$, we investigated the effect of previous PVN treatment with losartan, PD 123319, or [ $\left.\mathrm{Sar}^{1}, \mathrm{Ala}^{8}\right]$ ANG II (ANGII receptor antagonists) on the water and salt intake, urine and sodium excretion, and blood pressure responses induced by administration of ANG II into the (MSA).

\section{Methods}

Male albino Holtzman rats weighing 250-300 grams were used in all experiments. The rats were individually housed in a temperature-controlled room $\left(23 \pm 2^{\circ} \mathrm{C}\right)$ with a 12:12-hour light-dark cycle. Food pellets $\left(\mathrm{Na}^{+}\right.$content $5 \mathrm{mEq} / 100 \mathrm{~g}$ ) and water were available ad libitum except as noted. All experiments began at 09:00 AM. 
Animals were anesthetized with tribromoethanol (20 mg) per 100 grams of body weight, ip).

A stainless steel guide cannula $(0.6 \mathrm{~mm}$ outer diameter, $0.33 \mathrm{~mm}$ inner diameter was implanted into MSA by using the following coordinates: $1.20-1.00 \mathrm{~mm}$ anterior to the bregma in the midline, and to a depth of $4.2 \mathrm{~mm}$ from the dura mater. For cannula implantation into the PVN (unilaterally) the following coordinates were used: $0.2-0.6 \mathrm{~mm}$ lateral to the sagittal line, $6.0 \mathrm{~mm}$ down the dura mater and $1.8-2.0 \mathrm{~mm}$ posterior to the bregma. The cannula was secured to the top of the skull with dental cement and fastened with 2 screws. The insertion of a close fitting stylet kept the lumen free of debris and clots. A prophylactic dose of penicillin (30000 IU) was administered 3 days before and 3 days after surgery.

After brain surgery, the animals were returned to individual metabolic cages, with free access to granular rations and tap water for 1 week until the day of the experiment. A dental needle $(0.3 \mathrm{~mm}$ od $) 2.0-\mathrm{mm}$ longer than the cannula fixed to the skull was used for injections of all the drugs. The needle was connected by PE-tubing to a Hamilton-type syringe $(5 \mu \mathrm{L})$ kept outside the cage. All drugs were injected in a $0.5-\mu \mathrm{L}$ volumes for over $10-15$ seconds.

To determine the accuracy of MSA or PVN placement, the animals were was offered drinking water immediately after ANG II (10 nmol) injection. Water ingestion (4 mL) within 15 minutes of the injection was presumptive evidence of correct positioning of the cannula into the MSA or PVN. This test was performed at least 72 hours prior to the experiment for water and sodium intake.

Seven days after brain surgery, water and $3 \% \mathrm{NaCl}$ intake were measured in different groups after injection of saline $(0.15 \mathrm{M} \mathrm{NaCl})$ and ANG II (40 nmol) into the MSA. The effect of pretreatment with the ANG II receptor antagonists on ANG II-induced water or $3 \% \mathrm{NaCl}$ intake was tested with $\left[\mathrm{Sar}^{1}, \mathrm{Ala}^{8}\right]$ ANG II $(40 \mathrm{nmol})$, losartan (10 nmol), and PD 123319 (10 nmol) injected into the PVN 15 minutes before ANG II injection into the MSA. Water and $3 \% \mathrm{NaCl}$ intake were recorded at 30 -minute intervals for 2 hours after the injection of the antagonists.

Five days after brain surgery, catheters (PE-50 polyethylene tubing) were inserted with the animals anesthetized with 2,2,2-tribromoethanol ( $20 \mathrm{mg}$ ) per 100 grams of body weight into the superior vena cava via the right external jugular vein, with the opposite end externalized between the scapular. Two days after surgery, animals underwent the experimental session. After 12 hours of water and $3 \% \mathrm{NaCl}$ solution deprivation, the catheters were connected to $10-\mathrm{mL}$ syringes driven by a Harvard Apparatus infusion pump. Intravenous infusion of hypotonic saline $(0.08 \mathrm{M}$ at $1.5 \mathrm{~mL} /$ h) was started to promote urinary flow, and 3 hours were allowed for equilibration. Urine excretion was recorded at 30-minute intervals for 2 hours after injection of the ANG II antagonists. Different groups received isotonic saline and ANG II into the MSA, and the ANG II antagonists into the PVN 15 minutes before ANG II.

Mean arterial pressure (MAP) was recorded in unanesthetized and unrestrained rats through polyethylene tubing
(PE-10 connected to a PE-50) inserted into the abdominal aorta through the femoral artery with the animals anesthetized with 2,2,2-tribromoethanol (20mg/100g body weight) on the day before the recording. The polyethylene tube was tunneled subcutaneously to the back of the rat and was connected to a Statham (P23Db) pressure transducer (Statham-Gould) coupled to a multichannel recorder (Physiograph, Narco Bio-Systems). The drugs were injected according to the same protocol described above.

Angiotensin II and [Sar $\left.{ }^{1}, \mathrm{Ala}^{8}\right]$ ANG II (Sigma), losartan, and PD123319 (DuPont-Merck).

Sodium concentrations in urine samples were measured with a NOVA $1+1$ apparatus.

At the end of the experiments, the rats were anesthetized with ether and a $10 \%$ saline and $10 \%$ formalin solution was perfused through the heart. The brains were removed, fixed in $10 \%$ formalin for 1 week, frozen, cut into $20-30 \mu \mathrm{m}$ sections, and stained with hematoxylin.

Data are reported as means \pm SEM. The results were statistically examined by using one-way analysis of variance (ANOVA), followed by comparisons between individual means by using the Newman-Keuls post hoc test. Differences at the $5 \%$ level $(\mathrm{p}<0.05)$ were considered significant.

\section{Results}

Only animals in which the injection was placed in the MSA were used in this study. The PVN parameters studied were observed in subjects that had the injection placed in the lateral parvocellular and medial posterior magnocellular subdivisions of the PVN but not in subjects in which the injections were placed in the fornix, zona incerta, reuniens thalamic nucleus, dorsal and medial parvocellular, or periventricular subdivisions of the PVN.

Effects of [Sar $\left.{ }^{1}, \mathrm{Ala}^{8}\right]$ ANG II, losartan, or PD123319 injected into the PVN on water and saline ingestion induced by ANG II injected into the MSA.

The water ingestion observed during 2 hours of the control experiment $(0.15 \mathrm{M} \mathrm{NaCl})$ and with the injection of the angiotensin antagonists are presented in figure 1. Analysis of variance for the 2-hour cumulative water intake indicate that the different treatments significantly affect water intake, $F(4,50)=33.06$ ( $p<0.05)$. ANG II administration significantly increased water intake when compared with that of the saline controls. Cumulative water intake induced by ANG II was totally inhibited in animals previously treated with $\left[\mathrm{Sar}^{1}, \mathrm{Ala}^{8}\right]$ ANG II and losartan, and partially inhibited by previous treatment with PD 123319.

Analysis of variance was performed for the cumulative 2-hour saline intake, $F(4,51)=11.67(\mathrm{p}<0.05)$. The animals treated with ANG II significantly increased saline ingestion when compared with the controls (fig. 2). Previous injection of $\left[\mathrm{Sar}^{1}, \mathrm{Ala}^{8}\right]$ ANG II and losartan inhibited the saline ingestion induced by ANG II, whereas pretreatment with PD 123319 partially inhibited the saline intake induced by ANGII.

Injection of only $\left[\mathrm{Sar}^{1}, \mathrm{Ala}^{8}\right] \mathrm{ANG}$ II, losartan, or PD 
123319 into the PVN produced no alterations in water and salt intake.

Effects of $\left[\mathrm{Sar}^{1}, \mathrm{Ala}^{8}\right]$ ANG II, losartan, or PD 123319 injected into the $\mathrm{PVN}$ on diuresis and natriuresis, induced by ANG II injected into the MSA.

The urinary response of rats treated with ANG II and of rats pretreated with the antagonists is summarized in figure 3. Analysis of variance applied to the 2-hour cumulative urine excretion indicated a significant difference between groups, $\mathrm{F}(4,44)=14.13(\mathrm{p}<0.05)$. Cumulative urine excretion induced by ANG II was inhibited in animals previously treated with $\left[\mathrm{Sar}^{1}, \mathrm{Ala}^{8}\right]$ ANG II and PD 123319, but with no significant differences when compared with the saline controls, whereas previous injection of losartan decreased the urine excretion induced by ANG II indicating a significant difference when compared with saline controls.

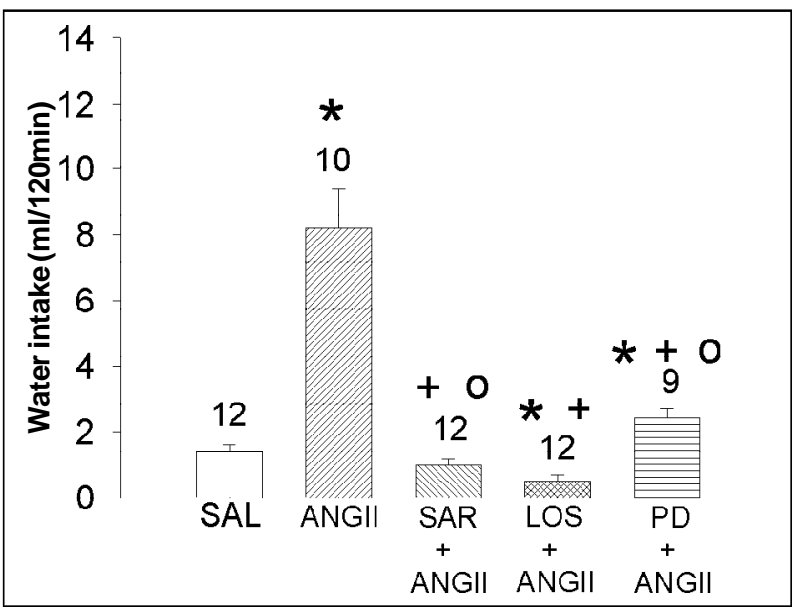

Fig. 1 - Water intake. Effect of pretreatment with $\left[\mathrm{Sar}^{1}, \mathrm{Ala}^{8}\right]$ ANG II $(40 \mathrm{nmol})$, losartan $(40 \mathrm{nmol})$, and PD123319 (40 nmol) into the PVN on water intake induced by injection of ANG II $(10 \mathrm{nmol})$ into the MSA. Data are reported as mean \pm SEM. The number of animals is indicated at the top of each column. " $\mathrm{p}<0.05$ compared with saline (control); ${ }^{+} \mathrm{p}<0.05$ compared with ANG II $;{ }^{0} \mathrm{p}<0.05$ compared with losartan.

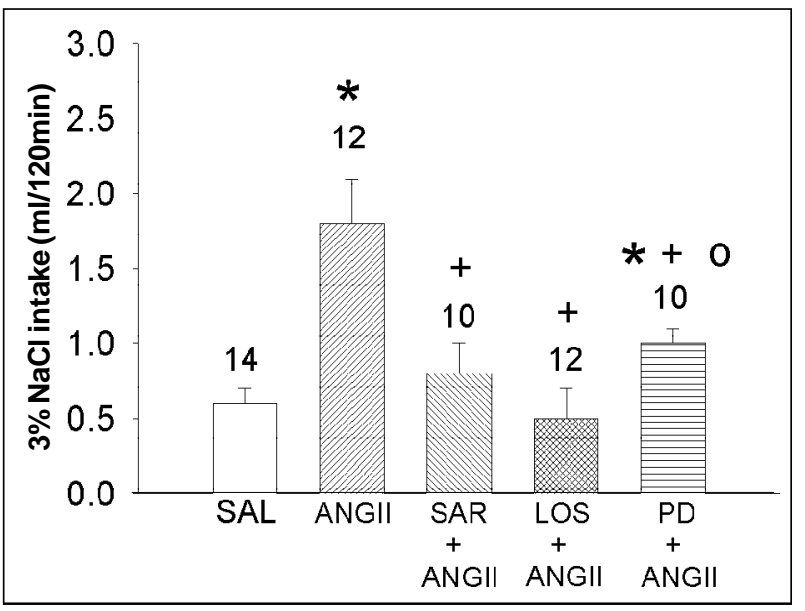

Fig. 2 - Sodium intake. Effect of pretreatment with $\left[\mathrm{Sar}^{1}, \mathrm{Ala}^{8}\right]$ ANG III (40 nmol), losartan $(40 \mathrm{nmol})$, and PD123319 (40 nmol) into the PVN on sodium intake induced by injection of ANG II ( $10 \mathrm{nmol})$ into the MSA. Data are reported as mean \pm SEM. The number of animals is indicated at the top of each column. ${ }^{*} \mathrm{p}<0.05$ compared with saline (control); ${ }^{+} \mathrm{p}<0.05$ compared with ANG II; ${ }^{\circ} \mathrm{p}<0.05$ compared with losartan.
Analysis of variance for the 2-hour cumulative sodium excretion data showed a significant difference between groups, $\mathrm{F}(4,44)=24.73(\mathrm{p}<0.05)$. As can be seen in figure 4 , sodium excretion induced by ANG II increased significantly compared with that in control rats. Animals with previous administration of [ $\left.\mathrm{Sar}^{1}, \mathrm{Ala}^{8}\right]$ ANG II blocked the sodium excretion induced by ANG II. The pretreatment with PD 123319 was more effective in decreasing the sodium excretion induced by ANG II when compared with the effects induced by previous administration of losartan.

Injection of only $\left[\mathrm{Sar}^{1}, \mathrm{Ala}^{8}\right]$ ANG II, losartan, or PD 123319 into the PVN produced no alterations in urine and sodium excretion.

Effects of [ $\left.\mathrm{Sar}_{1}, \mathrm{Ala}_{8}\right]$ ANG II, losartan, or PD 123319 injected into the PVN on the increase of arterial pressure induced by ANG II injected into the MSA.

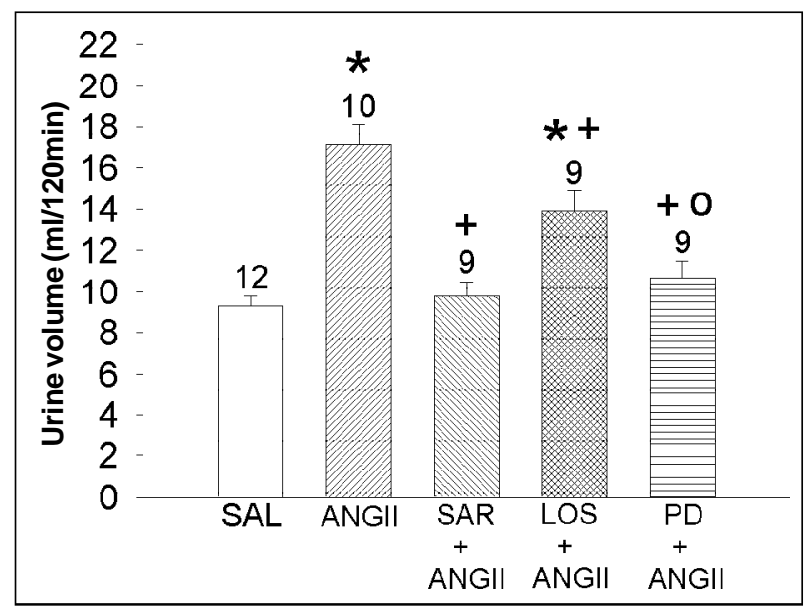

Fig. 3 - Urine excretion. Effect of pretreatment with $\left[\mathrm{Sar}^{1}, \mathrm{Ala}^{8}\right]$ ANG II $(40 \mathrm{nmol})$ losartan (40 nmol), and PD123319 (40 nmol) into the PVN on urine excretion induced by injection of ANG II $(10 \mathrm{nmol})$ into the MSA. Data are reported as mean \pm SEM The number of animals is indicated at the top of each column. ${ }^{*} \mathrm{p}<0.05$ compared with saline (control); ${ }^{+} \mathrm{p}<0.05$ compared with ANG II; ${ }^{\circ} \mathrm{p}<0.05$ compared with losartan.

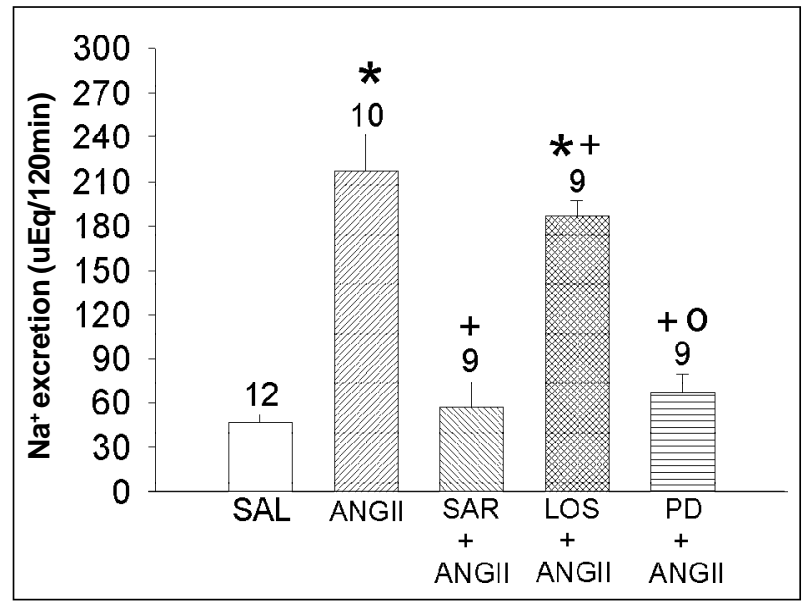

Fig. 4 - Sodium excretion. Effect of pretreatment with $\left[\mathrm{Sar}^{1}, \mathrm{Ala}^{8}\right]$ ANG II $(40 \mathrm{nmol})$ losartan $(40 \mathrm{nmol})$, and PD123319 $(40 \mathrm{nmol})$ into the PVN on sodium excretion induced by injection of ANG II $(10 \mathrm{nmol})$ into the MSA. Data are reported as mean \pm SEM. The number of animals is indicated at the top of each column. ${ }^{*} \mathrm{p}<0.05$ compared with saline (control); ${ }^{+} \mathrm{p}<0.05$ compared with ANG II; ${ }^{\circ} \mathrm{p}<0.05$ compared with losartan. 
The injection of ANG II $(10 \mathrm{nmol} / 0.5 \mu \mathrm{L})$ into the MSA, of conscious normotensive rats (MAP $=114 \pm 4$ to $123 \pm 6 \mathrm{mmHg}$ in different groups) produced an immediate large increase in MAP $(\triangle \mathrm{MAP}=24 \pm 4 \mathrm{mmHg})$ compared to the results when only $(0.15 \mathrm{M} \mathrm{NaCl})$ was injected into the MSA (6 $\pm 2 \mathrm{mmHg}$ ) (fig. 5). The largest pressor response after ANG II injection into the MSA was reached within 3 minutes, with 10-30 minutes needed for the values to return to baseline.

Previous injection of [ $\left.\mathrm{Sar}^{1}, \mathrm{Ala}^{8}\right]$ ANG II $(40 \mathrm{nmol})$ and losartan $(10 \mathrm{nmol})$ into the PVN fully eliminated whereas PD $123319(40 \mathrm{nmol})$ partially blocked the pressor response induced by ANG II injection.

\section{Discussion}

The results of the present study confirm reports that the dipsogenic and sodium intake action of centrally administered ANG II can be stopped by $\mathrm{AT}_{1}$ receptor antagonist ${ }^{24,25}$. In addition, the data show that the $\mathrm{AT}_{2}$ receptor antagonist, PD 123319, also causes a marked reduction in the effects of ANG II on water and sodium intake. After injection of losartan into the PVN, the effects of MSA injection of ANG II on water and sodium ingestion were stopped, indicating that the actions of ANG II were exerted through $\mathrm{AT}_{1}$ receptors. However, PD 123319 injected into the PVN also inhibited the effects of ANG II, although these effects were not as strong as those observed for losartan.

The present data also show that the $\mathrm{AT}_{1}$ receptor antagonist causes a reduction in the effects of ANG II on water and sodium excretion. After injection of PD 123319 into the PVN, the effects of injection of ANG II into the MSA on urine and sodium excretion were totally stopped, indicating that the actions of ANG II were exerted principally through $\mathrm{AT}_{2}$ receptors.

The present data also show that the hypertensive

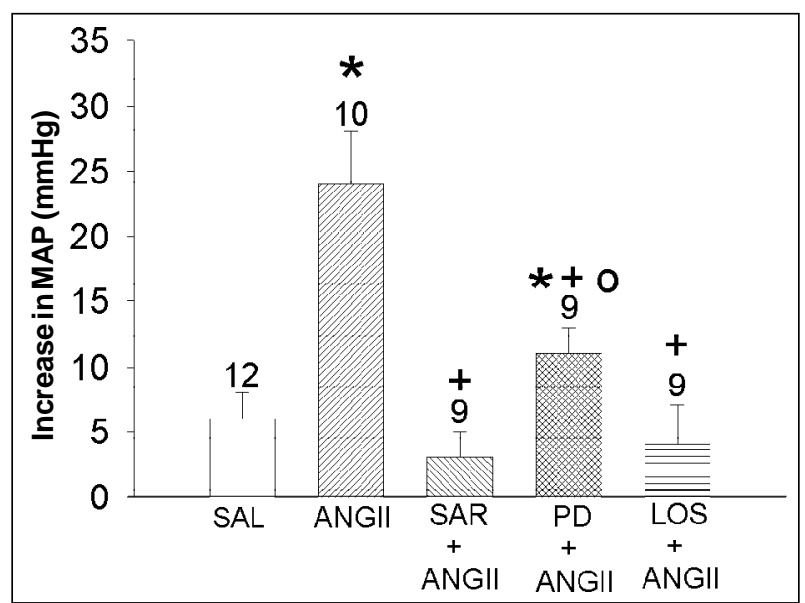

Fig. 5 - Medial arterial pressure. Effect of pretreatment with $\left[\mathrm{Sar}^{1}, \mathrm{Ala}^{8}\right] \mathrm{ANG}$ II $(40 \mathrm{nmol})$, losartan $(40 \mathrm{nmol})$, and PD123319 $(40 \mathrm{nmol})$ into the PVN on MAP changes induced by injection of ANG II ( $10 \mathrm{nmol})$ into the MSA. Data are reported as mean \pm SEM. The number of animals is indicated at the top of each column. ${ }^{*} p<0.05$ compared with saline (control); ${ }^{+} \mathrm{p}<0.05$ compared with ANG II; ${ }^{\circ} \mathrm{p}<0.05$ compared with losartan. effect of ANG II administered into the MSA was eliminated by losartan and reduced but not eliminated by PVN administration of PD 123319.

Data about $\mathrm{AT}_{2}$ antagonists centrally administered are controversial. Intracerebroventricular (icv) administration of the $\mathrm{AT}_{2}$ antagonists, $\mathrm{PD} 123319, \mathrm{PD} 123177$, and CGP 42112 have shown inhibition, no change, or an increase in water and sodium intake and pressor response to icv ANG II ${ }^{17}$. Several works have shown inhibitory responses to icv administration of PD 123319 on water and salt intake, vasopressin release, and pressor responses to central ANG II in rats ${ }^{7,25-28}$, but central administration of PD 123177 or CGP 42112 has not been shown to interfere with these responses ${ }^{24,28}$. PVN administration of CGP 42112A eliminated the diuretic, natriuretic, and kaliuretic effects of ANG II injected into the same area ${ }^{29}$. Functional evidence exists that ANG II exerts excitatory effects on neurons of the PVN and that these effects are antagonized by CGP $42112 \mathrm{~A}^{19}$.

The MSA actions of ANG II on water and sodium intake, urinary and sodium excretion, and increases in arterial blood pressure are dependent on coactivation of both $\mathrm{AT}_{1}$ and $\mathrm{AT}_{2}$ receptor subtypes. It has been demonstrated that PD 123319 and EXP-3174 (an active metabolite of losar$\tan$ ), administered icv eliminate the cardiovascular response to ANG II ${ }^{28}$. The cardiovascular and behavioral effects of PD 123319 were remarkably similar to those of substance P, suggesting that PD 123319 may act by releasing endogenous substance $P$. It has been suggested that the inhibitory effects of relatively high doses of PD 123319 injected icv may be due to action on central $\mathrm{AT}_{1}$ receptors ${ }^{30}$. Both $\mathrm{AT}_{1}$ and $\mathrm{AT}_{2}$ receptor subtypes in the brain have effects similar to those of ANG II-induced water and $\mathrm{NaCl}$ intake ${ }^{25}$ and eliminate the cardiovascular response to ANG II injected icv ${ }^{29}$ or into the hypothalamus ${ }^{31}$.

In summary, the $\mathrm{AT}_{1}$ and $\mathrm{AT}_{2}$ receptors of the MSA may influence the cardiovascular and hydroelectrolyte alterations induced by ANG II. The present data show that $\mathrm{AT}_{1}$ receptors of the PVN eliminate the water and sodium intake and the blood pressure response, and attenuate the diuretic and natriuretic actions of ANG II injected into the MSA. The $\mathrm{AT}_{2}$ receptors of $\mathrm{PVN}$ play a role in blocking urine and sodium excretion, and alter the water and sodium intake and the pressor response induced by injection of ANG II into the MSA. These data suggest that MSA efferents may release ANG II, which acts as a neurotransmitter within $\mathrm{PVN}$, resulting in postsynaptic effects that in turn influence fluid-electrolyte and blood pressure control as has been demonstrated by connections with the subfornical organ and supraoptic nucleus and septal area ${ }^{32}$.

\section{Acknowledgments}

The authors appreciate the technical assistance of Reginaldo C. Queiróz, Silas P. Barbosa, Silvia Fóglia, Alexandre A. Vieira and Silvana A. D. Malavolta. They also thank Ana V. Oliveira for animal care. Research was supported by CNPq, FAPESP, and FUNDUNESP. 


\section{References}

1. Johnson AK. Neurobiology of the periventricular tissue surrounding the anteroventral third ventricle (AV3V) and its role in behavior, fluid balance, and cardiovascular control. In: DA, Smith, RA, Galosy and SM, Weiss (Eds.), Circulation Neurobiology and Behavior. New York: Elsevier, 1982: 277-96.

2. Phillips MI. Functions of angiotensin in the central nervous system. Annu Rev Physiol 1987; 49: 413-35.

3. Reid JA. Actions of angiotensin II on brain: mechanisms and physiological role. Am J Physiol 1984; 246: F533-F43.

4. Gutman MB, Jones DL, Ciriello J. Lesions of the paraventricular nucleus of the hypothalamus attenuate the pressor and drinking response to angiotensin II acting at the subfornical organ. Soc Neurosci Abst 1986; 12: 1174

5. Jensen L, Harding JW, Wright JW. Role of paraventricular nucleus in control of blood pressure and drinking in rats. Am J Physiol 1992; 262: F1068-75.

6. Cowley AW, Switer SJ Jr, Skelton MM. Vasopressin, fluid and electrolyte response to chronic angiotensin II infusion. Am J Physiol 1981; 240: R130-R8.

7. Ferguson AV, Renaud LP. Systemic angiotensins acts at subfornical organ to facilitate activity of neurohypophysial neurons. Am J Physiol 1986; 251: R712-R17.

8. Franci CR, Silva-Netto CR, Saad WA, Camargo LAA, Antunes-Rodrigues J. Interaction between the lateral hypothalamic area (LHA) and the medial septal area (MSA) in the control of sodium and potassium excretion in rats. Physiol Behav 1986; 25: 801-6.

9. Gelsema A, Calaresu FR. Chemical microstimulation of the septal area lowers arterial pressure in rat. Am J Physiol 1987; 252: R760-R7.

10. Leite DF, Camargo LAA, Saad WA, et al. Role of cholinergic and adrenergic pathways of the medial septal area in the control of water intake and renal excretion in rats. Pharmacol Biochem Behav 1992; 42: 1-8.

11. Luiz AC, Saad WA, Camargo LAA, Renzi A, De Luca LA Jr, Menani JV. Pressor, dipsogenic, natriuretic and kaliuretic responses to central carbachol in rats with lesion of the medial septal area. Neurosc Lett 1991; 132: 195-8.

12. Morita N, Saad WA, Camargo LAA, Silva-Netto CR, Antunes-Rodrigues J, Covian MR. Interaction between the septal area and subfornical organ in the control of water intake induced by thirst-eliciting procedures. Physiol Behav 1980; 24: 243-9.

13. Tanaka J, Saito H, Seto K. Involvement of the septum in the regulation of paraventricular vasopressin neurons by the subfornical organ in the rat. Neurosc Lett 1988; 92: 187-91.

14. Lenkei Z, Palkovits M, Corvol P, Llorens-Cortes C. Expression of angiotensin type-1 $\left(\mathrm{AT}_{1}\right)$ and type-2 $\left(\mathrm{AT}_{2}\right)$ receptor mRNAs in the adult rat brain: a functional neuroanatomical review. Front Neuroendocrinol 1997; 18: 383-439.

15. Song K, Allen AM, Paxinos G, Mendelsohn FAD. Mapping of angiotensin II receptor subtype heterogenety in rat brain. J Comp Neurol 1992; 316: 467-84.

16. Allen AM, Moeller I, Jenkins TA, et al. Angiotensin receptors in the nervous system. Brain Res Bull 1998; 47: 17-28.
17. McKinley MJ, McAllen RM, Pennington GL, Smardencas A, Weisinger RS, Oldfield BJ. Physiological actions of angiotensin II mediated by AT and AT receptors in the brain. Clin Exp Pharmacol Physiol 1996; 3: S99-S104.

18. Ambühl P, Felix D, Imboden H, Khosla MC, Ferrario CM. Effects of angiotensin analogues and angiotensin receptor antagonists on paraventricular neurons. Regul Pept 1992; 38: 111-20.

19. Felix D, Khosla MC, Barnes KL, Imboden H, Montani B, Ferrario CM. Neurophysiological responses to angiotensin (1-7). Hypertension 1991; 17: 1111-4.

20. Schiavone MT, Brosnihan KB, Khosla MC, Ferrario CM. Angiotensin II activation of vasopressin release in the rat hypothalamus neurohypophysial system is mediated by the type 2 angiotensin receptor. Hypertension Abst 1991; 17: 425 .

21. Wright JW, Harding JW. Brain angiotensin receptor subtypes in the control of physiological and behavioral responses. Neurosci Biobehav Rev 1994; 18: 21-53.

22. Negoro H, Visesswawan S, Holland RC. Inhibition and excitation of units in paraventricular nucleus after stimulation of the septum, amygdala, and neurohypophysis. Brain Res 1973; 57: 479-83.

23. Paxinos G, Watson C. The Rat Brain in Stereotaxic Coordinates Atlas. San Diego: Academic Press, 1986.

24. Beresford MJ, Fitzsimons JT. Intracerebroventricular angiotensin II-induced thirst and sodium appetite in rat are blocked by the $\mathrm{AT}_{1}$ receptor antagonist, losartan (DuP753), but not by the $\mathrm{AT}_{2}$ antagonist, CGP42112B. Exp Physio 1992; 77: 761-4.

25. Rowland NE, Rozelle A, Riley PJ, Fregly J. Effect of nonpeptide angiotensin receptor antagonists on water intake and salt appetite in rats. Brain Res Bul 1992; 29: 389-93.

26. Cooney AS. Two angiotensin subtype 2 receptor antagonists have dissimilar effects on angiotensin II-induced drinking in rat. J Physiol 1994; 480: 85P.

27. Rowland NE. Brain AT- 2 receptor antagonism and water intake Brain Res Bull 1994; 32: 391-4.

28. Widdop RE, Gardiner SM, Kemp PA, Bennett T. Differencial blockade of central effects of angiotensin II by $\mathrm{AT}_{2}$-receptor antagonists. Am J Physiol 1993; 265 : H226-H31.

29. Camargo LAA, Saad WA. Renal effects of angiotensin II receptor subtype 1 and 2selective ligands injected into the paraventricular nucleus of conscious rats. Regul Pept 1999; 84: 91-6.

30. Cooney AS, Fitzsimons JT. The effect of putative AT ${ }_{2}$ agonist, p-aminophenylanine6-angiotensin II, on thirst and sodium appetite. Exp Physiol 1993; 78: 767-74.

31. Ham NL, Sim MK. Hypothalamic angiotensin receptor subtypes in normotensive and hypertensive rats. Am J Physiol 1998; 275: H703-H708.

32. Ferguson AV, Bourque CW, Renaud LP. Subfornical organ and supraoptic nucleus connections with septal neurons in rats. Am J Physiol 1983; 251: R712- R17. 